\title{
ACUTE MYOCARDIAL INFARCTION;
}

SERUM ZINC LEVEL IN PATIENTS

Dr. Mashooq Ali Dasti, Dr. Syed Fasih Ahmed Hashmi, Dr. Ghulam Hussain Baloch, Dr. Syed Zulfiquar Ali Shah.

ABSTRACT.....OBJECTIVE: To determine the serum zinc level in patients with acute myocardial infarction at Liaquat University Hospital Hyderabad. PATIENTS AND METHODS: This six months study was conducted on the patients with acute myocardial infarction presented at coronary care unit (CCU) of Liaquat University Hospital Hyderabad. All the patients with myocardial infarction, of $\geqslant 30$ years of age and either gender diagnosed as acute myocardial infarction were admitted and evaluate for their serum zinc level by taking 2cc fasting venous blood sample on admission and at one or two day interval thereafter. The data entered, saved and analyze in SPSS version 11.00. RESULTS: Total 142 patients with acute MI were registered for study. Of these $92(64.8 \%)$ were males and $50(35.2 \%)$ were females. The mean age \pm SD for male and female was $54.98 \pm 11.88$ and $50.52 \pm 9.85$ respectively. Regarding plasma zinc level, hypozincemia (low zinc level) was observed in $90(63 \%)$ patients, of which $53(58.9 \%)$ were males and $37(41.1 \%)$ were females while the $52(37 \%)$ subjects had normozincemia (normal zinc level). In $33(36.7 \%)$ patients the serum zinc was low at admission, 38(42.4\%) patients had hypozincemia on 3rd day of admission while $19(21.1 \%)$ had low serum zinc level on 5th day of admission. The mean \pm SD for serum zinc level in overall population was $9.78 \pm 2.31$ and the mean $\pm S D$ of patients with hypozincemia was $7.85 \pm 3.42$, whereas the mean $\pm S D$ of patients with normozincemia was $16.85 \pm 2.53$. During hospitalization the complications of acute MI identified in hypozincemic population were cardiac arrhythmias, cardiac failure, pericarditis, recurrent infarction, thromboembolism and mitral regurgitation. CONCLUSION: It is observed that serum zinc level appears to be low in patients with acute myocardial infarction.

Key words: Zinc, myocardial infarction, hypozincemia

\section{Article Citation}

Dasti MA, Hashmi SFA, Baloch GH, Shah SZA. Acute myocardial infarction; serum zinc level in patients. Professional Med J 2013;20(4): 556-561.

\section{INTRODUCTION}

Coronary artery disease (CAD) and its end result, myocardial infarction (MI) continue to be a significant cause of mortality and morbidity in the western world". Over the past 50 years, it has become clear that the cascade of thrombotic events following atherosclerotic plaque rupture causes occlusion of the coronary artery, interrupting blood supply and oxygen to myocardium thus resulting in infarction ${ }^{2}$. Myocardial necrosis following infarction is followed by heart failure, myocardial rupture or arrhythmias ${ }^{3}$. Early treatment of myocardial ischaemia to prevent necrosis with treatments such as fibrinolysis, coronary artery bypass grafting and percutaneous coronary intervention have improved outcome ${ }^{4}$. Over time it has become clear that in order for such treatments to be of maximal benefit, timely diagnosis is important. Here, biomarkers become important, to help us improve our diagnostic accuracy of the disease, as treatments are not without risk. Furthermore, biomarkers also provide prognostic information about the disease, which then aids clinicians in deciding how aggressively they need to treat the disease.

Zinc is metallic element having atomic number 30 and symbol $\mathrm{Zn}$. It is an essential mineral for sustaining human and animal life 5 . Zinc is the $23^{\text {rd }}$ most abundant element in the Earth's crust and most heavily found element in mines in the shape of ores sphalerite which roughly contain $01 \%$ iron as well as $40-50 \%$ zinc $^{6}$. It is required for structure and function of large number of enzymes and over 300 enzymatic reactions, it has catalytic as well as structural role. Zinc is present in high concentration in liver, eggs, milk and dairy products, un-milled cereals, legumes, pulses, oil seeds, and in vegetables like spinach and lettuce ${ }^{7}$. In human body zinc is present in large amount in skin and prostate, its concentration is average in bones, teeth; whereas its concentration is low in kidney, muscles, heart, pancreas, and spleen. Small amount of zinc is 
also present in brain and lungs ${ }^{5}$.

Serum zinc levels have been shown to fall after acute tissue injury including myocardial infarction ${ }^{8}$. In myocardial infarction the levels fall within one or two days of the onset, and then rise to reach normal levels in 10 to 14 days $^{8}$. The clinical studies had been little attempt to correlate the zinc levels with other biochemical measurements, or with prognosis. Thus, it is not yet established whether measurement of plasma zinc has any practical value in myocardial infarction. Therefore the purpose of this study was to evaluate the value of serial plasma zinc measurements in patients with acute myocardial infarction.

\section{METHODS}

This cross sectional case series study was conducted in department of cardiology at Liaquat University Hospital from July 2011 to December 2011. All the patients with $\geqslant 35$ years of age, of either gender, presented at coronary care unit (CCU) of Liaquat University Hospital Hyderabad and were diagnosed as acute myocardial infarction were recruited and enrolled in the study. The diagnosis of AMI was made on the presence of any of the two parameters mentioned below.

a. Onset of typical retrosternal pain or discomfort of recent onset lasting for 20-30 minutes.

b. Electrocardiogram (ECG) evidence of persistently ST segment elevation in two or more contiguous leads followed by $T$ wave inversion. The appearance of $Q$ waves of more than 0.045 second duration or $>4 \mathrm{~mm}$ depth

c. Rise and fall of serum cardiac biomarkers such as creatine kinase (CK-MB) fraction, Lactate dehydrogenase (LDH) and troponin.

- The serum CK-MB Activity>24U/Litre

- SerumLDH > 170/Litre

- $\quad$ Troponin T (will be identified through Trop T kit)

I. One line (control line) = Negative

II. Two lines (control \& signal line) $=$ Positive

III. Noline $=$ Invalid
The electrocardiography was performed on arrival in cardiology department and six hourly for one day, then once daily by me or ECG technician. The cardiac enzymes; on arrival of the patient then at two, four, eight, twelve and twenty four hours on first day and then once daily for seven days by taking 2cc venous blood sample in a 5cc disposable syringe. The troponin $\mathrm{T}$ rapid assay which is a qualitative immunological test for the detection of Troponin $\mathrm{T}$ in the blood was performed with a test card containing monoclonal antibodies on bed side with the help of pipette (provided in the kit) 150 micro liter of the patients heparinized venous blood sample was applied on application well of the test card and the results were read after 20 minutes of blood application. A written consent was taken from attendants of the patients for participation in the study. Depending on severity every patient was put on a cardiac monitor and vital signs were recorded every four hours for the first three days then thrice daily.

In Parallel, the subjects were assessed for their serum zinc level by taking 2cc fasting venous blood sample on admission and at one or two day interval thereafter. The normal range of serum zinc level is $11-19 \mathrm{mmol} / \mathrm{L}$ (cut-off), and the value $<11 \mathrm{mmol} / \mathrm{L}$ was considered as low while the value $>19$ was labeled as high ${ }^{9}$.

The exclusion criteria of the study were the patients already on zinc therapy, who were known cases of any autoimmune disease, immunodeficiency disorder (CD4 + count $<200$, granulocytopenia $<500 / \mathrm{mm} 3$ ), already on cancer chemotherapy and hormonal therapy, the patients had history of acute or chronic diarrhea and the pregnant ladies. The data was collected on pre-designed proforma and all such maneuvers were under medical ethics. The data was then entered, saved and analyzed in SPSS version 11.00. The frequency and percentage was calculated for zinc status in patients with acute myocardial infarction. The chi-square test was applied between categorical variables at $90 \%$ confidence interval and 
the $p$-value $\leqslant 0.10$ was considered as statistically significant.

\section{RESULTS}

Total 142 patients with acute MI were registered for study. Of these $92(64.8 \%)$ were males and $50(35.2 \%)$ were females. The mean age \pm SD for male and female was $54.98 \pm 11.88$ and $50.52 \pm 9.85$ respectively. Regarding plasma zinc level, hypozincemia (low zinc level) was observed in 90 (63\%) patients (Table:I)

\begin{tabular}{|c|c|c|c|c|}
\hline \multicolumn{5}{|c|}{ Serum zinc } \\
\cline { 1 - 4 } Gender & Low & Normal & Total & P-value \\
\hline Male & $53(58.9 \%)$ & $39(75 \%)$ & $92(64.8 \%)$ & \multirow{2}{*}{$0.053^{*}$} \\
\hline Female & $37(41.1 \%)$ & $13(25 \%)$ & $50(35.2 \%)$ & \\
\cline { 1 - 4 } Total & $90(100 \%)$ & $52(100 \%)$ & $142(100 \%)$ & \\
\cline { 1 - 3 } Table-I. Frequency of hypozincemia in patients \\
with acute myocardial infarction \\
*P-value is statistically significant \\
\hline
\end{tabular}

Whereas the variation in serum zinc during hospitalization is shown in (Table:Il)

\begin{tabular}{|c|c|c|c|c|}
\hline \multicolumn{5}{|c|}{ Serum zinc } \\
\cline { 1 - 4 } & Low & Normal & Total & P-value \\
\cline { 1 - 4 } At admission & $33(36.7 \%)$ & $30(57.7 \%)$ & $63(44.4 \%)$ & \\
\cline { 1 - 4 } At day 03 & $38(42.2 \%)$ & $14(26.9 \%)$ & $52(36.6 \%)$ & \multirow{2}{*}{0.051 * } \\
\cline { 1 - 4 } At day 05 & $19(21.1 \%)$ & $08(15.4 \%)$ & $27(19.0 \%)$ & \\
\cline { 1 - 3 } Total & $90(100 \%)$ & $52(100 \%)$ & $142(100 \%)$ & \\
\cline { 1 - 3 } & & &
\end{tabular}

Table-II. Serum zinc status during hospitalization *P-value is statistically significant

The mean \pm SD for serum zinc level in overall population was $9.78 \pm 2.31$ and the mean \pm SD of patients with hypozincemia was $7.85 \pm 3.42$, whereas the mean $\pm S D$ of patients with normozincemia was $16.85 \pm 2.53$.During hospitalization the complications of acute Ml identified in hypozincemic population are shown in Table:Ill.

\begin{tabular}{|c|c|c|c|c|}
\hline \multicolumn{5}{|c|}{ Hypozincemia $(n=90)$} \\
\hline Complication & Male & Female & Total & P-value \\
\hline Cardiac arrhythmias & 07 & 08 & $15(16.6 \%)$ & \\
\hline Cardiac failure & 07 & 10 & $17(18.8 \%)$ & \\
\hline Pericarditis & 05 & 09 & $14(15.5 \%)$ & \\
\hline Recurrent infarction & 03 & 05 & $08(8.8 \%)$ & \\
\hline Thromboembolism & 09 & 06 & $15(16.6 \%)$ & \\
\hline Mitral regurgitation & 04 & 05 & $09(10 \%)$ & \\
\hline No any (Nil) & 07 & 05 & $12(13.3 \%)$ & \\
\hline
\end{tabular}

Table-III. Complications observed in hypozincemic patients

\section{DISCUSSION}

Zinc is a vital element in maintaining the normal structure and physiology of cells. The fact that it has an important role in states of cardiovascular diseases has been studied and described by several research groups and observed to have protective effects in coronary artery disease and cardiomyopathy. In present study the hypozincemia was identified in 90/142(63\%) patients with male population predominant $53 / 90(58.9 \%)$. In a study by Vasto, et $\mathrm{a}^{10}$ twenty healthy adults were given $45 \mathrm{mg}$ of zinc every day for 6 months and compared to a control group of 20 healthy adults taking a placebo (no zinc). The zinctaking adults had significant reduction in inflammatory factors that are otherwise known to directly contribute to cardiovascular disease and shown that a lack of zinc increases the risk for early death. The zinc, like magnesium, is vital to the function of numerous enzymes involved in human health including inflammation reduction and important for immunity, boosting infection-fighting systems as well as reducing the risk for prostate cancer ${ }^{11}$. The zinc lowered the levels of C-reactive protein, interleukin 6 , macrophage chemoattractant protein 1 , vascular cell adhesion molecule 1, secretory phospholipase A2, malondialdehyde, and hydroxyalkenals. Each of these compounds, when elevated, indicate either inflammatory or free radical damage is occurring 
within the circulation in a way that contributes to cardiovascular disease $^{12}$.

In our study we observed the fall of serum zinc level in first 03 days i.e. at admission 33(36.7\%) and at third day $38(42.2 \%)$. The specificity of plasma zinc estimation as a diagnostic test in myocardial infarction may be estimated by using Bayes' theorem, the study by Katz identified the probability of a positive zinc test (minimum plasma zinc fall in the first three days) and represented myocardial infarction was 80 percent $^{13}$. The time course of changes in plasma zinc is particularly fortunate for the diagnosis of myocardial infarction. Since the level falls in the first few days and does not return to normal levels for 01 to 02 weeks, it enables both acute and recent infarcts to be detected.

The minimum serum zinc indicates a significant correlation with enzymes and clinical indices of prognosis. We observed that the fall in serum zinc level is the most clinically useful measure of zinc changes in acute myocardial infarction.

The precise reason for hypozincemia in acute myocardial infarction is still unknown. Serum zinc has been shown to fall after administration of steroids ${ }^{14}$. It is possible that the fall after myocardial infarction may be steroid-related, though the peak in plasma cortisol occurs within the first 12 hours while the fall in plasma zinc takes somewhat longer ${ }^{15}$. During stress the humoral factor is released that is produced by polymorphs (leucocyte endogenous mediator, or LEM), which depresses plasma zinc levels, and increases zinc uptake by the liver ${ }^{16}$. An alpha2macroglobulin containing a large amount of zinc has been isolated, and proposed as a transport protein ${ }^{17}$. The level of this carrier protein is raised in myocardial infarction and other states associated with a fall in plasma zinc. In present study, regarding the $90(63 \%)$ hypozincemic patients with acute $\mathrm{MI}$, the complications were observed in $78(87 \%)$ subjects, of which cardiac arrhythmia and thromboembolism was predominant, the finding is also consistent with the study by Low, et al ${ }^{18}$.

Therefore intracellular zinc plays a critical role in the signaling pathway, whereas certain triggers such as ischemia and infarction lead to release of zinc from proteins and cause myocardial damage. In such circumstances, replenishing with zinc has been shown to improve cardiac function and prevent further damage. So the portion of zinc homeostasis is emerging in cardiovascular disease research and decrease of zinc in serum probably could be of prognostic as well as diagnostic significance. The hypothesis needs further advance and multidisciplinary studies in relation to hypozincemia, extent of myocardium damage and its pathophysiologic significance.

\section{CONCLUSION}

The zinc can influence different mechanisms for cardiovascular health and considered as a necessary nutrient for those at higher level of cardiac risk. In present study it is observed that serum zinc level appears to be low in patients with acute myocardial infarction. The hypozincemia may be involved in the induction and sustaining of myocardium tissue injury. In patients with myocardial infarction there is a good correlation between the minimum plasma zinc level and the clinical estimation of prognosis.

\section{Copyright $\subset 12$ Feb, 2013.}

\section{REFERENCES}

1. Biyik I, Canbaz MA, Ergene 0 . Seasonal variability of acute myocardial infarction in a Western Anatolian city and its relations to acute infections and climate. Int Angiol. 2007;26(3):285-89.

2. Goyal A, Spertus JA, Gosch K, Venkitachalam L, Jones $P G$, Van den Berghe $G$, et al. Serum potassium levels and mortality in acute myocardial infarction. JAMA. 2012;307(2):157-64.

3. Piccini JP, Berger JS, Brown DL. Early sustained ventricular arrhythmias complicating acute 
myocardial infarction. Am J Med. 2008;121(9):797804.

4. Tunstall-Pedoe H, Vanuzzo D, Hobbs M, Mahonen M, Cepaitis Z, Kuulasmaa K, Keil U. Estimation of contribution of changes in coronary care to improving survival, event rates, and coronary heart disease mortality across the WHO MONICA Project populations. Lancet. 2000;355:688-700

5. Rink L, Gabriel P. Zinc and immune system. Proc Nutr Soc 2000;59:541-2

6. Powell SR. The antioxidant properties of zinc. J Nutr. 2000;130(5S Suppl):1447S-54S

7. Dhingra U, Hiremath G, Menon VP, Dhingra P, Sarkar A, Sazawal S. Zinc deficiency: descriptive epidemiology and morbidity among preschool children in periurban population in Delhi, India. J Health Popul Nutr. 2009;27(5):632-9.

8. Handjani AM, Smith JC, Herrmann JB, Halsted JA. Serum zinc concentration in acute myocardial infarction. Chest. 1974;65;185-7

9. Soomro AA, Devrajani BR, Shaikh K, Shah SZA, Devrajani T, Bibi I. Serum zinc level in patients with liver cirrhosis. PakJ Med Sci. 2009;25(6):986-91.

10. Vasto S, Mocchegiani E, Malavolta M, Cuppari I, Listì F, Nuzzo D, et al. Zinc and inflammatory/immune response in aging. Ann N Y Acad Sci.2007;1100:11122
11. Shankar AH, Prasad AS. Zinc and immune function: the biological basis of altered resistance to infection. Am J Clin Nutr.1998;68(2 Suppl):447S-463S.

12. Prasad AS. Zinc: role in immunity, oxidative stress and chronic inflammation. Curr Opin Clin Nutr Metab Care. 2009;12(6):646-52

13. Katz MA. A probability graph describing the predictive value of a highly sensitive diagnostic test. N Engl J Med. 1974;291:1115-17

14. Flynn A, Pories WJ, Strain WH, Hill OA Jr, Fratianne RB. Rapid serum-zinc depletion associated with corticosteroid therapy. Lancet.1971;2(7735):116972 .

15. Adair R, Kasahara M. Serum cortisol response to acute myocardial infarction in the aged. J Am Geriatr Soc. 1980;28(10):472-74.

16. Pekarek RS, Wannemacher RW Jr, Beisel WR. The effect of leukocytic endogenous mediator (LEM) on the tissue distribution of zinc and iron. Proc Soc Exp Biol Med. 1972;140(2):685-88.

17. McBean LD, Smith JC Jr, Berne BH, Halsted JA. Serum zinc and alpha2-macroglobulin concentration in myocardial infarction, decubitus ulcer, multiple myeloma, prostatic carcinoma, Down's syndrome and nephrotic syndrome. Clin Chim Acta.1974;50 (1):43-51.

18. Low WI, Ikram H. Plasma zinc in acute myocardial infarction. Diagnostic and prognostic implications. $\mathrm{Br}$ Heart J.1976;38(12):1339-42.

\section{AUTHOR(S):}

\section{DR. MASHOOQ ALI DASTI}

Consultant Cardiologist

Liaquat University of Medical and Health Sciences (LUMHS), Jamshoro, Pakistan.

2. DR. SYED FASIH AHMED HASHMI

Associate Professor

Department of Cardiology

Liaquat University of Medical and Health Sciences (LUMHS), Jamshoro, Pakistan.

\section{DR. GHULAM HUSSAIN BALOCH}

Associate Professor

Liaquat University of Medical and Health Sciences (LUMHS),

Jamshoro, Pakistan.

\section{Dr. Syed Zulfiquar Ali Shah}

Department of Medicine

Liaquat University of Medical and Health Sciences (LUMHS), Jamshoro, Pakistan.

\section{Correspondence Address:}

Dr. Mashooq Ali Dasti

House \# 279, Doctor's Colony Hirabad Hyderabad,

Sindh, Pakistan.

zulfikar229@hotmail.com 


\section{PREVIOUS RELATED STUDIES}

Abid R.A, Ali L, Mohyuddin T, Naveed S, Ahmed M.S, Azhar M. ACUTE MYOCARDIAL INFARCTION; EVIDENCE FOR A SEX-AGE INTERACTION (Original) Prof Med Jour 13(2) 178-185 Apr, May, Jun, 2006.

Ahmad A, Tanvir H.Z, Hussain Z. ACUTE MYOCARDIAL INFARCTION; SERUM MAGNESIUM AND ELECTROLYTE LEVELS AT PRESENTATION IN EMERGENCY DEPARTMENT (Original) Prof Med Jour 17(2) 246-251 Apr, May, Jun 2010.

Malik A.I , Mahmood K, Raja K.M. ACUTE MYOCARDIAL INFARCTION (Original) Prof Med Jour 12(4) 457-465 0ct, Nov, Dec 2005.

Hafeez S, Javed A, Kayani M.A. ACUTE MYOCARDIAL INFARCTION; SIGNIFICANCE OF $1^{\text {sT }}$ SET OF CK-MB IN DIAGNOSIS(Original) Prof Med Jour 16(2) 198-201 Apr, May, Jun, 2009.

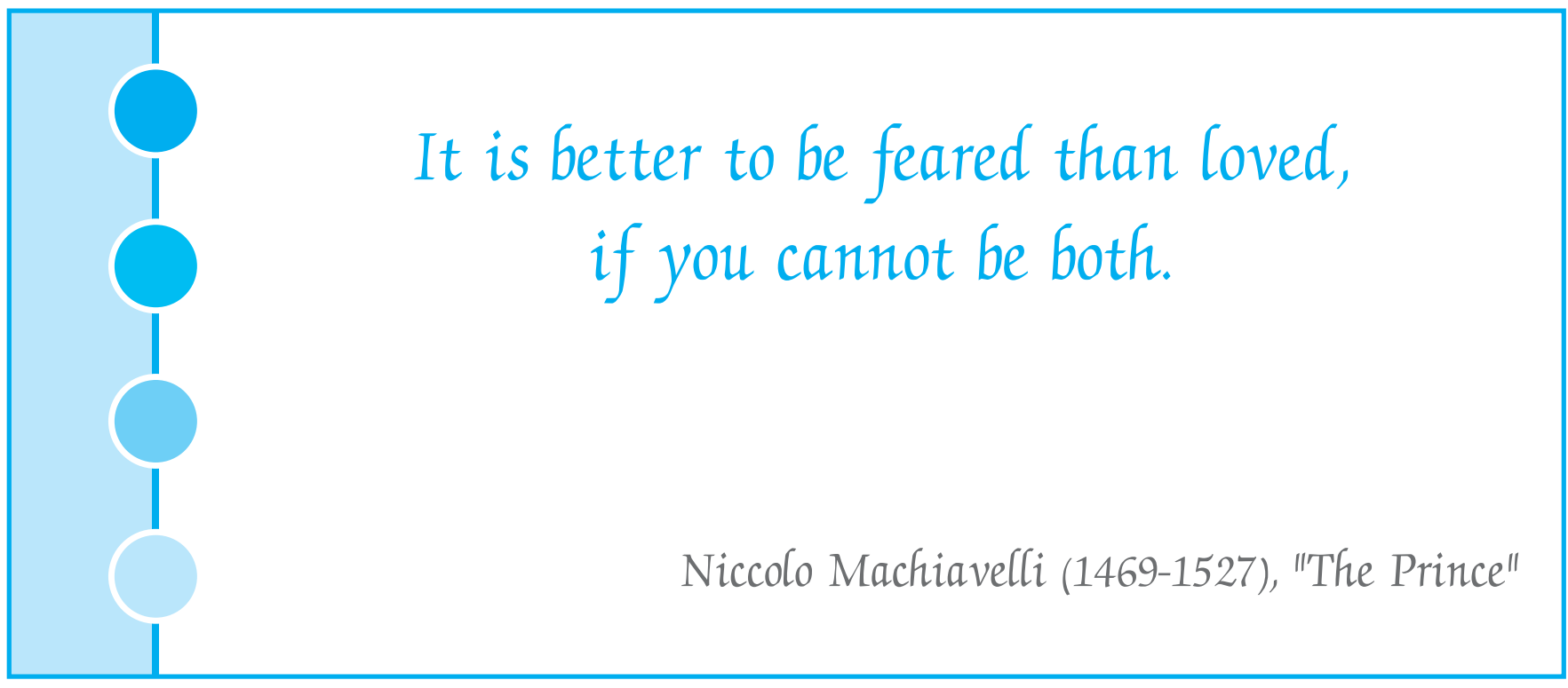

